\title{
JEMURAN IKAN ASIN OTOMATIS BERBASIS INTERNET OF THINGS UNTUK
}

\section{DAERAH PESISIR PANTAI PANTURA}

\author{
Rais $^{1 *}$, Nurohim ${ }^{2}$ \\ Email : ${ }^{1}$ rais.hojawa@gmail.com, ${ }^{2}$ nurohim77@gmail.com \\ Prodi DIII Teknik Komputer, Politeknik Harapan Bersama \\ Jl. Mataram No. 9 Pesurungan Lor Tegal
}

\begin{abstract}
Abstrak
Saat ini penanganan ikan tidak hanya ditunjukan untuk mempertahankan kesegaran ikan akan tetapi dalam pengolahan ikan kering juga menjadikan penanganan utama dalam proses pengeringan. Ikan asin merupakan salah satu produk olahan yang banyak dikonsumsi oleh masyarakat Indonesia.. Mayarakat dipesisir pantai laut utara (pantai pantura) mayoritas sebagai nelayan. Hasil tangkapan ikan sebagian ada yang dijual sebagai ikan segar dan ada yang diolah menjadi ikan asin. Ikan asin yang diolah diawetkan secara tradisional. Proses pengawetan secara tradisional bertujuan untuk mengurangi kadar air dalam tubuh ikan, sehingga tidak memberikan kesempatan bagi bakteri untuk dapat berkembang biak. Hasil pengawetan yang bermutu tinggi dapat diperoleh dengan perlakuan yang baik selama proses pengawetan seperti menjaga kebersihan bahan dan alat yang digunakan. Proses pengawetan ikan asin di daerah pesisir pantura dilakukan dengan cara pengeringan yaitu menjemur ikan depan rumah kadang dijalan. Proses pengeringan dengan cara menjemur ditempat terbuka sangat kurag efektif dan efisien jika terjadi hujan secara tiba-tiba yang dapat menyebabkan ikan basah atau rusak karena terkena air hujan yang dapat mengakibatkan ikan asin mudah terkena bakteri dan tidak higienis. Sehingga solusi untuk menyelesaikan permasalahn tersebut dibuatlah jemuran ikan asin otomatis dengan memanfaatkan hairdrayer sebagai pemanas atau pengganti matahari dengan dan sesor DHT11 serta sensor ultrasonic untuk monitoring suhu yang mudah di monitoring melalui website. Sistem pengeringan otomatis dengan berbasis internet of Things dengan memanfaatkan pemanas hairdrayer dengan ruangan yang tertutup mampu menghasilkan produk ikan asin yang higeinis. Sistem pengeringan dengan model ini memberikan kemudahan dalam kondisi cuaca apapaun karena tidak memerlukan sinar matahari. Dalam penelitian ini metode yang digunakan adalah metode waterfall dengan tahapan Requirements Analysis, Design, Implementation, Testing, Maintenance.
\end{abstract}

Kata kunci: Jemuran, Ikan asin, monitoring, IoT

\section{Pendahuluan}

Ikan asin merupakan makanan pavorit selain mudah mendapatkanya ikan asin ini memiliki protein yang tinggi yaitu kandungan protein ikan asin per 100 gram sebesar $42 \%$. Kandungan lemak ikan asin sebesar $1,50 \%$ lebih rendah dari pada ikan segar yaitu $4,50 \%$. Kendala akan kesulitan selain pemasaran untuk pengusaha pengasinan ikan bersekala kecil, terletak pada pengeringan ikan. Pada umumnya proses pengeringan ikan masih cara tradisional dalam mengeringkan ikan hasil tangkapan dan masih menggantungkan diri pada alam, yaitu sinar matahari [1]. Pengeringan cara ini biasanya dilakukan dengan meletakan produk di atas jaring ikan, tikar, hamparan lantai semen atau anyaman bambu dan ditempatkan dibawah sinar mata hari. Metode ini tidak higienis dan memungkinkan produk yang dikeringkan kehilangan sebagian beratnya atau rusak karna dimakan kucing, serangga atau hewan lainya [2]. selain itu faktor terjadinya hujan secara tiba tiba dapat menjadikan rusaknya ikan asin yang sedang dijemur sehingga hasil yang diperoleh tidak maksimal karna bayak ikan asin yang rusak. Permasalahan yang sering mucul ketika penjemuran adalah lupa mengangkat jemuran ketika sedang hujan, dalam survei yang dilakukan ada $85 \%$ orang yang pernah lupa mengangkat jemuran ketika hujan [3].

Seperti halnya dalam menjemur ikan asin, faktor lupa saat menjemur merupakan 
hal yang sering terjadi. Berdasarkan survei yang telah dilakukan, ketika musim penghujan, mayoritas orang khususnya pelaku industri ikan asin di daerah pesisir pantai pantura merasa khawatir saat menjemur ikan asin, kekhawatiran tersebut bertambah ketika sedang terjadi hujan secara mendadak dan dampaknya ikan tidak bisa kering dengan sempurna, yang menyebabkan kualititas ikan asin jadi menurun dan keterlambatan waktu dalam proses produksi ikan asin itu sendiri. Dengan melihat permasalahan tersebut maka perlu di buat jemuran ikan asin otomatis dengan dengan memanfaatkan Internet of Things (IoT).

Dalam penelitian yang dilakukan oleh Younce M. Bintang dkk, tahun 2013, dalam penelitian yang berjudul Kontruksi dan Kapasitas Alat Pengering Ikan Tenaga Surya Sistem Bongkar-Pasang pada penelitian ini menggunakan metode eksperimen yaitu suatu bentuk penelitian yang dilakukan dengan cara mengubah suatu keadaan untuk melihat kejadian yang timbul akibat dari perubahan itu, alat pengering ini dibuat seperti type Efek Rumah Kaca (ERK)-hybrid, yang dapat memanfaatkan panas dan tenaga surya. Capaian suhu maksimal dalam alat pengering sampai $50 \mathrm{oC}$ dengan suhu luar maksimal 38 oC. pada pengering ikan selama 14 jamdengan suhu rata-rata $45 \mathrm{oC}$ dapat menurunkan kadar air ikan sampai 37oC dan dengan nilai organoleptic $>7$. Hal ini sesuai dengan kadar maksimal $40 \%$ dan nilai organoleptic minimal 7 [2].

Penelitian lain yang dilakukan oleh Benardie Bimo dkk, tahun 2018 dengan penelitianya yang berjudul Jemuran Pakaian Portabel Berbasis Internet of Things (IoT), hasil dari penelitian ini adalah sistem jemuran dapat berjalan baik ketika cuaca sedang hujan maupun panas, ketika cuaca hujan atap akan menutup dan menyalakan kipas yang ada untuk proses pengeringan, sedangkan saat cuaca panas atap akan membuka dan kipas akan mati . sistem ini berjalan berdasarkan prakiraan cuaca yang akan terjadi selama beberapa jam kedepan, ketika prakiraan cuaca di API Weather mendeteksi akan terjadi hujan maka atap akan langsung menutup dan kipas akan langsung nyala, semua proses itu dilakukan berdasarkan prakiraan cuaca dari wilayah yang didapat oleh GPS smartphone atau dipilih secara manual oleh pengguna [3].
Penelitian yang dilakukan oleh Yusak Mukkun dkk, tahun 2016, dengan judul penelitian Pembuatan Alat Pengering Ikan Ramah Lingkungan dengan Menggunakan Integrasi Panel Surya dan Sinar Matahari Langsung pada penelitian ini dijelaskan bahwa alat pengering ikan asin ramah lingkungan menggunakan integrasi panel surya dan energy matahari merupakan hasil pengembangan energi terbarukan yaitu pemanfaatkan energi matahari baik secara langsung maupun secara tidak langsung dengan penyimpanan solar cell.

\section{Metode Penelitian}

Dalam rencana penelitian ini menggunakan metode Waterfall/ SDLC (System Development Life Cycle) dengan tahapan sebagai berikut (Blanchard\& Fabrycky, 2006) :

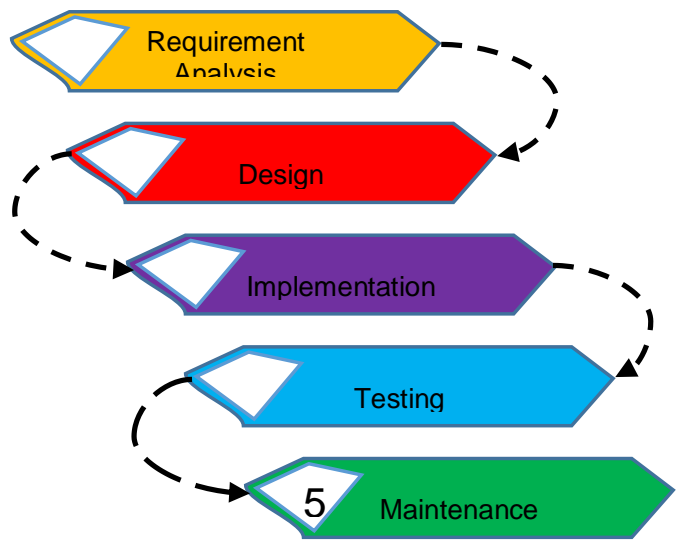

Gambar 1. Prosedur penelitian

Gambaran umum perancangan sistem yang akan dibuat, sistem pertama melalui kontrol dari web. Mikrokontroler melakukan autentikasi Wi-Fi. suhu akan dikontrol sesuai dengan inputan dari halaman web kontrol. Perancangan sistem berikutnya berjalan secara otomatis Sensor suhu mendeteksi outputan dari hairdryer, hasil dari pembacaan suhu akan dikirim ke database, kemudian ditampilkan ke website secara real time beserta informasi yang lebih lengkap. Perancangan sistem yang lebih spesifik akan digambarkan dalam bentuk Flowchart dan Use Case Diagram. 


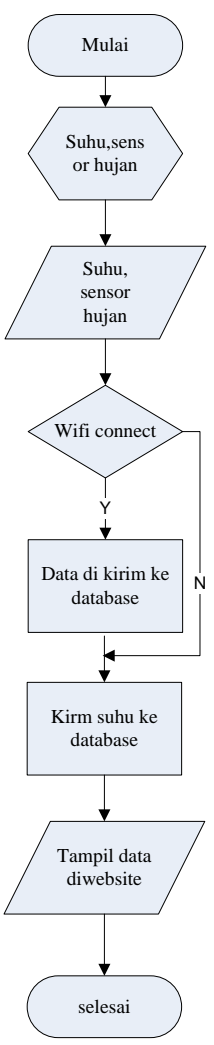

Gambar 2 Flowchart Perancangan Sistem Verifikasi

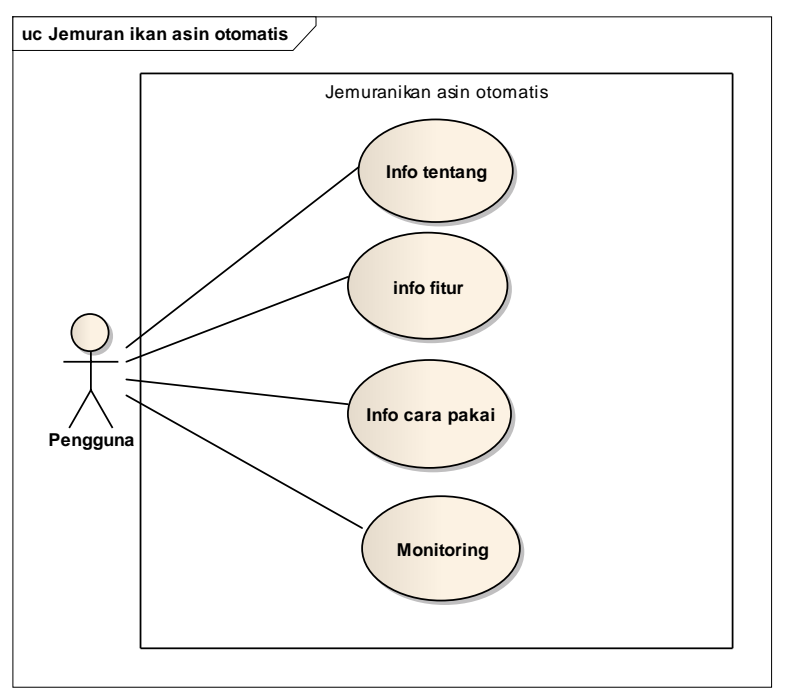

Gambar 3 Use Case Sistem Pengeringan Ikan Asin

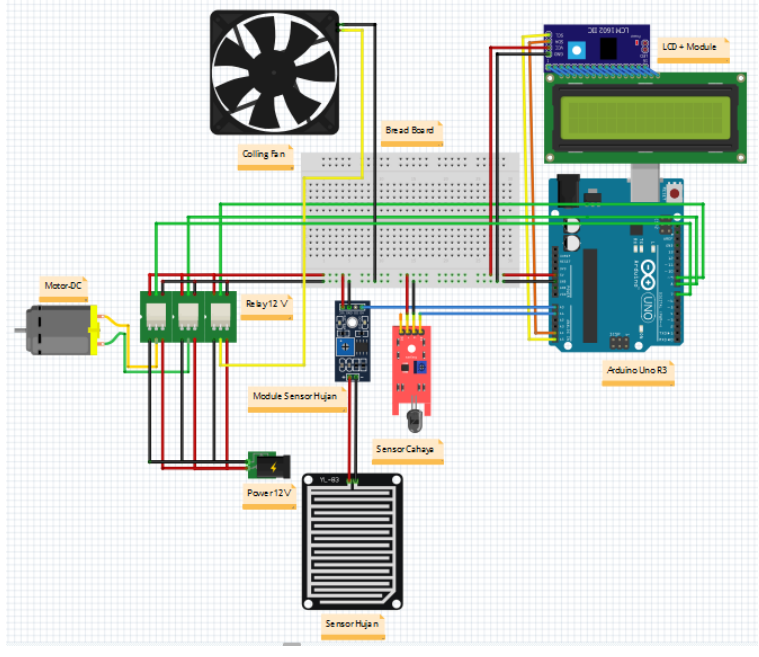

Gambar 4 Diagram Block

\section{Hasil dan Pembahasan}

Telah diperoleh hasil penelitian ini adalah jemuran ikan asin otomatis berbasis Internet ofThings untuk daerah Pesisisr Pantai Pantura melalui website menggunakan sensor DHT 11 dan sensor hujan berbasis Arduino Uno dan Wemos ESP8266. Sistem ini terdari dari beberapa bagian utama serta tampilan monitoring melalui website seperti yang ditunjukan pada gambar :

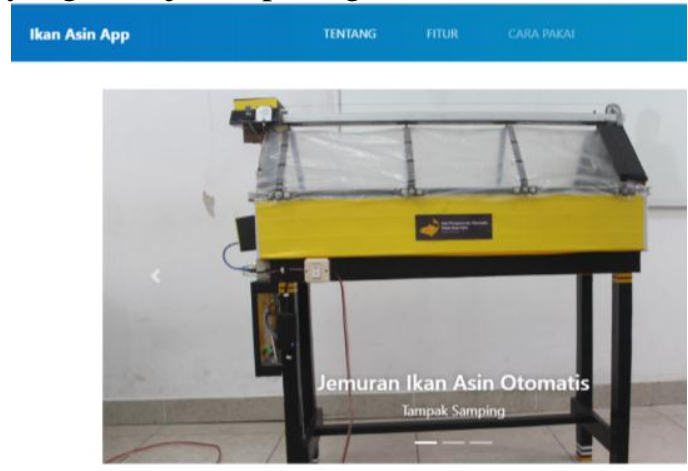

Gambar 5. Halaman interface Halaman Monitoring

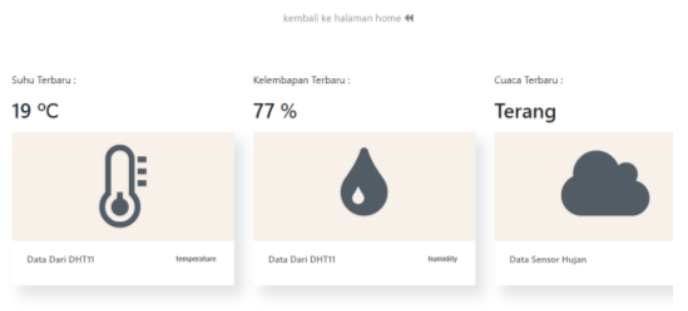

Gambar 6. Halaman monitoring 


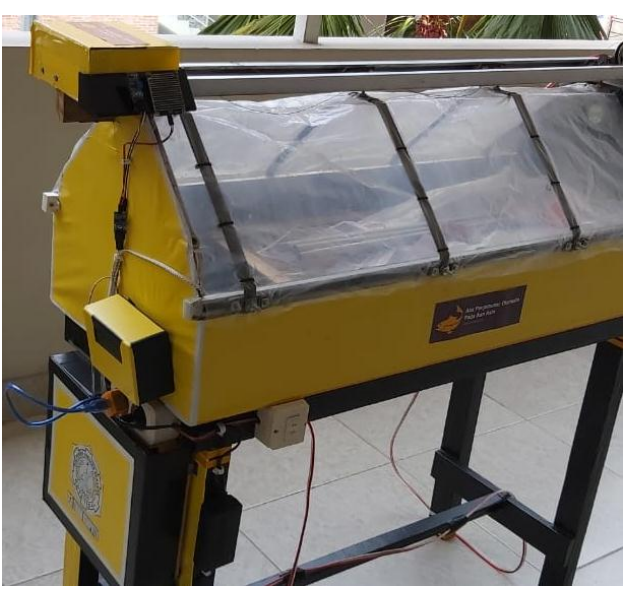

Gambar 7. Rangkaian Alat Pengeringan

\section{Kesimpulan}

Berdasarkan hasil analisa dan pengujian yang telah dilakukan. Metodologi yang diterapkan dalam membuat jemuran ikan asin ini adalah metode SDLC (System Development Life Cycle) dengan mengunakan pengujian metode black box untuk fungsionalitas dari tiap tiap fitur. Hasil pengujian menunjukan bahwa tiap tiap fitur pada sistem telah berfungsi dengan baik. Sehingga jemuran ikan asin ini dapat membantu para pelaku IKM dalam menjemur ikan asin agar kualitas dari ikan asin tersebut tetep terjaga.

\section{Daftar Pustaka}

[1] Yusak Mukkun, dkk. 2016. "PEMBUATAN ALAT PENGERING IKAN RAMAH LINGKUNGAN DENGAN MENGGUNAKAN INTEGRASI PANEL SURYA DAN SINAR MATAHARI LANGSUNG." Jurnal Ilmiah FLASH 19-25

[2] Younce M Bintang, dkk. 2013. "KONTRUKSI DAN KAPASITAS ALAT PENGERING IKAN TENAGA SURYA SISTEM BONGKAR PASANG." Jurnal Media Teknologi Hasil Perikanan 4043.

[3] Benardie Bimo, dkk. 2018. "JEMURAN PAKAIAN PORTABEL BERBASIS IOT." eProceeding ofApplied Science. Bandung. 669-674.

[4] Pitowarno, Endra. 2012. ROBOTIKA, desain,kontrol, dan kecerdasan buatan, Yogyakarta : Andi.

[5] Rismawan, Eko. 2012." Jurnal Informatika dan Teknik Elektro
Terapan"Jurusan Teknik Elektro Fakultas Teknik Universitas Lampung.

[6] Sumisjakartono, 1987. Elektronika Praktis untuk pemula, hobbyist, dan wiraswatawan, PT Elex Media Komputindo.

[7] M. D. Pinem, "Rancang Bangun Alat Pengering Ikan Teri Kapasitas 12 Kg/Jam," Jurnal Teknik SIMETRIKA, pp. 249-253, 2004.

[8] A. P. Pratama, "Implementasi Alat Pengeringan Ikan Otomatis Menggunakan Sensor Suhu DS18B20," 2017.

[9] I. Priyadi, "Perancangan Modul Pengeringan Ikan Putaran Rak Vertikal Berbasis Mikrokontroler," 2017. 
